\title{
Effect of Soaked and Fermented African Locust Bean Seeds Meal on the Performance, Organs and Carcass Characteristics of Broiler Chickens
}

\author{
Mu'azu Shu'aibu. Tamburawa ${ }^{1}$, Samson Olabanji Ogundipe ${ }^{2}$, Titus Samuel BabatundeTegbe ${ }^{2}$, \\ Taiye Sunday. Olugbemi ${ }^{2}$, Muhammad Rabiu Hassan ${ }^{2}$ \\ ${ }^{1}$ Animal Science Department, Kano University of Science and Technology, Wudil, Nigeria \\ ${ }^{2}$ Animal Science Department, Ahmadu Bello University Zaria, Samaru, Nigeria
}

Email address:

muazutambura@gmail.com (Mu'azu Shu'aibu. T.)

\section{To cite this article:}

Mu'azu Shu'aibu. Tamburawa, Samson Olabanji Ogundipe, Titus Samuel Babatunde Tegbe, Taiye Sunday. Olugbemi, Muhammad Rabiu Hassan. Effect of Soaked and Fermented African Locust Bean Seeds Meal on the Performance, Organs and Carcass Characteristics of Broiler Chickens. Animal and Veterinary Sciences. Vol. 5, No. 1, 2017, pp. 8-14. doi: 10.11648/j.avs.20170501.12

Received: January 5, 2017; Accepted: January 14, 2017; Published: February 22, 2017

\begin{abstract}
This research was conducted to determine the performance, organs weights and carcass characteristics of broiler chickens fed diets containing soaked and fermented African locust bean (Parkia biglobosa) seed meal (SFALBSM). Five diets were formulated in which SFLSBM was included in the diets broilers at graded levels of 0, 7.5, 15, 22.5 and 30\% designated as T1, T2, T3, T4 and T5 respectively. Two hundred and twenty five (225) broiler chickens (Marshall Strain) were fed these diets in a completely randomized design (CRD). Each treatment was replicated three times with 15 birds per replicate having forty five birds (45) per treatment. The experiment lasted 8 weeks (4weeks for starter phase and 4week for finisher phase). At the end of the experiment, carcass analysis was carried out in which three birds were slaughtered from each replication. The results of performance at starter phase showed were significant differences $(\mathrm{P}<0.05)$ in the final body weight $(734.25-919.89 \mathrm{~g})$, total weight gain $(679.13-898.31 \mathrm{~g})$ and total feed intake $(1572.39-1708.56 \mathrm{~g})$. The feed conversion ratio (1.87-2.31) were significantly $(\mathrm{P}<0.05)$ better for $15 \%$ SFALBSM diet compared to others. The results of performance of birds at finisher phase also showed there were significant differences $(\mathrm{P}<0.05)$ in the final body weights $(2312.73-2786.14 \mathrm{~g})$, total feed intake (4287.73-4373.88g), feed conversion ratio(3.05 -4.55) and feed cost per kilogram gain ( $\$ 222.33-316.70)$. Broilers fed $15 \%$ SFALBSM had significantly higher $(\mathrm{P}<0.05)$ in weights compared to others $(2786.14 \mathrm{~g})$. The values for carcass weight and dressing percentage were also significantly $(\mathrm{P}<0.05)$ higher for broilers fed $15 \%$ SFALBSM diet $(1930.24$ and $73.98 \%$ respectively). There were significant differences $(\mathrm{P}<0.05)$ in breast muscle $(17.35 \%-21.97 \%)$, drum stick $(10.74-11.60 \%)$ and thigh muscles (11.63-13.38\%). There were significant differences $(\mathrm{P}<0.05)$ in the heart $(0.49-0.50 \%)$, lungs $(0.50-0.70 \%)$, liver $(1.93-2.50 \%)$, pancreas $(0.20-0.32 \%)$ and kidney weights $(0.28-0.38 \%)$. Feed conversion ratio and feed cost per kilogram gain were better in broiler chickens fed 15\% SFALBSM diets (3.26 and $222.33 \mathrm{~N} / \mathrm{kg}$ gain respectively) compared to others. It was therefore concluded that soaked and fermented African locust bean seeds can be included in the diet of broiler chickens up to $15 \%$ without any detrimental effect on performance, carcass and organs weights.
\end{abstract}

Keywords: African Locust Bean Seed, Soaking and Fermentation, Broiler Chickens, Performance and Carcass Characteristics

\section{Introduction}

Feed is the most important input in a profitable poultry production. It accounts for $70-80 \%$ of total the cost of production [1], [2]. At present, the high cost of conventional feedstuffs has brought about the need to have alternative feedstuffs that can replace the expensive ones in order to reduce the cost of livestock production [3], [4]. Nigeria like many developing countries of the world has protein deficiency gap, especially that of high quality animal protein. This low animal protein intake has very serious implications on the health status and well-being of the citizenry [5]. The 
shortage of animal protein intake among the ever increasing human population in the third world countries has long been recognized [6]. Poultry production especially broiler chicken is one of the fastest way of achieving adequate animal protein supply for the Nigerian populace due to their short generation interval and rapid growth rate [7]. This is due to their genetic makeup when adequately nourished and managed [8].

Non conventional feedstuffs offer the best alternatives in our environment for reducing feed cost and therefore a reduction in the cost of meat and animal products [9]. The search for alternative sources of protein from legume crops in lieu of expensive ones has been advocated [10]. However, legume seeds contain anti-nutritional factors like enzymes inhibitors, phytate, oxalates, saponin and polyhenolic compounds, which limit their utilization [11]. Fortunately, remarkable improvement in the nutritive value and quality of legume seeds has been achieved by the application of various processing methods through research efforts [12].

The African locust bean tree is a leguminous plant which produces seed grain that is often cheaper and readily available in northern Nigeria. It grows in the savannah region of Nigeria, to the southern edge of zone[13\}, [14]. African locust bean seed is rich in protein and is used as a flavor intensifier for soups and stew [12]. The protein content of seeds varies between 25 and $30 \%$ and has the potential to be utilized in livestock feeding [15]. This research is aimed at investigating the nutritive value of soaked and fermented African locust bean (Parkia biglobosa) and its effects on growth performance, organs and carcass characteristics seeds meal of broiler chickens.

\section{Materials and Methods}

\subsection{Experimental Site}

This experiment was conducted at the Teaching and Research Farm of the Department of Animal Science, Faculty of Agriculture and Agricultural Technology, Kano University of Science and Technology, Wudil. Wudil local Government is located in the Sudan savannah region of Nigeria and the farm is located on latitude $11^{\circ} 37^{\prime} \mathrm{N}$ and longitude $8^{\circ} 58^{\prime} \mathrm{E}$ at an altitude of $403 \mathrm{~m}$ above sea level [16].

\subsection{Sources of African Locust Bean Seeds}

African Locust bean seeds were purchased from Dawakinkudu weekly market. The market is located in the Southern part of Kano state, Nigeria. The predominant variety of African locust bean tree available in Kano State is Parkia biglobosa, which is widely distributed in the area.

\subsection{Processing of Locust Bean Seeds Soaking and Fermentation}

Two hundred and fifty grams $(250 \mathrm{~g})$ sample of locust bean seeds were cleaned washed and poured into a container containing 2 litres of portable water. It was allowed to soak for 24 hours, excess water was removed and the sample was allowed to ferment for 3 days in an air tight polythene bags. Fermented seeds were removed after 3 days and spread in aluminium metal trays to sun dry for 3 days.

\subsection{Proximate Analysis and Determination of Anti-nutritional Factors}

The proximate composition of the raw and soaked and fermented ALBSM samples was carried out according the method of [17]. Thisanalysis was conducted at Animal Science Biochemistry laboratory of the Faculty of Agriculture, A.B.U. Zaria. (Table 1). The anti-nutritional factors determination in the raw and processed African locust bean seeds were also were also determined and percent of reduction was also calculated and compared (Table 2).

\subsection{Experimental Diets}

Five diets were formulated containing soaked and fermented African locust bean seeds meal (ALBSM) at dietary levels of $0,7.5,15,22.5$ and $30 \%$ designated as Treatment 1, 2, 3, 4 and 5 respectively. Broiler starter and finisher diets were formulated for the experiment (Table 3 and 4).

\subsection{Experimental Animals and Design}

Two hundred and twenty five (225) day old broiler chicks (Marshall strain) were used for the experiment. Having taking the initial weights, diets were allocated to chicks in a completely randomized design (CRD). Forty five (45) chicks were fed per treatment and each treatment was replicated 3 times with 15 birds per replicate. The birds were raised on deep litter house partitioned into pens measuring $2.10 \mathrm{~m}$ in length, $2.10 \mathrm{~m}$ wide and $1.25 \mathrm{~m}$ in height. The birds were vaccinated against Newcastle diseases at two (2) and four (4) weeks respectively. Feeds and water were offered ad libitum.

\subsection{Data Collection}

The birds were weighed at the beginning of the experiments and reweighed on weekly basis to determine the weight gain at starter and finishers phases. Consequently, a known quantity of feed was offered daily and the feed consumed by birds was determined by subtracting a leftover from the quantity of feed offered to chickens every day. Birds were placed into an empty bucket and weighed with $10 \mathrm{~kg}$ weighing scale on weekly basis to determine the daily weight gain. The feed conversion ratios were calculated as ratio of daily feed consumed to daily weight gains. At the end final body weights of birds were also taken and the initial body weight was subtracted for determination of total weight gain of birds. Mortality was recorded as it occurred.

At the end of the experiment, carcass analysis was carried out in which three birds from each replicate were randomly chosen and starved for 24 hours before slaughtering. The final live weights of birds were recorded before slaughtering. The birds were bled by slaughtering, immersed in hot water, defeathered and eviscerated. Carcass weights and meat cut 
parts (back, drumstick, thigh and wings) were weighed. All the values obtained were expressed as percentage of the live weight of birds. Similarly, the gut weights (crop, proventriculus, gizzard, small intestine weight, and large intestine weights) were measured using a portable electric digital weighing scale. The weights of visceral organs were also expressed as percentage of body weights.

\subsection{Data Analysis}

Data generated were subjected to Analysis of variance (ANOVA) using the general linear model of statistical analysis system [18].

Statistical model used was $\mathrm{Y}_{\mathrm{ij}}=\mu+\mathrm{Pi}+$ eij, Where:

$\mathrm{Y}_{\mathrm{ij}}=$ the $\mathrm{j}^{\text {th }}$ observation of the $\mathrm{i}^{\text {th }}$ processing of seeds by soaking and fermentation.

$\mu=$ the overall estimate of the population mean

$P_{i}=$ the effect of the $i^{\text {th }}$ processed seeds by inclusion in diets (T1, T2, T3, T4 and T5)

$\mathrm{E}_{\mathrm{ij}}=$ the random error.

\section{Results and Discussion}

The results of proximate composition of raw and processed African locust bean seeds meal are presented in (Table 1). The protein content was slightly improved $(28.56 \%)$ and the level of fibre content was also reduced (10.27\% compared) to raw seeds (24.31 and 13.55 respectively. [19] Reported that fermentation improved palatability besides upgrading the nutrient composition of the fermented material. The results on anti-nutritional factors with percentage reduction were presented in Table 2. There were some reductions of the level of anti-nutrients when the by soaked and fermented for three days seeds compared to raw. This agreed with work of [20] who reported that soaking and fermentation reduced the level of toxic compound in legume seeds. This could be due to the positive effect of fermentation which led to the improvement of the protein which is presumed to be used by fermenting microbes [21].

The results on performance of broiler chickens during the starter phase (0-4 weeks) are presented in Table 5. The results showed there were significant differences $(\mathrm{P}<0.05)$ in the final weight again and total weight gain of broilers fed soaked and fermented diets. The final weight gain was better for chicks fed control diets and $15 \%$ having $919.89 \mathrm{~g}$ and $937.81 \mathrm{~g}$ respectively. While, the lowest value of final body weight was recorded for birds fed 30\% SFALBSM diet $(734.25 \mathrm{~g})$. This is in line with report of [22] who stated that soaking and fermentation facilitates microbial and enzymes action on certain anti-nutritional factor in grain legumes thereby enhancing better utilization of nutrients. The chicks fed $\mathrm{T} 1$ and $\mathrm{T} 3$ had significantly $(\mathrm{P}<0.05)$ higher total weight gain compared to others. This finding is supported by [23] who reported that fermentation action products allow for increased utilization of feed by chickens.

The results on performance of broiler chickens at finisher phase fed SFALBSM diets are presented in Table 6. There were significant $(\mathrm{P}<0.05)$ differences in final body weight and total weight gain of birds. Final body weight of broilers was highest for diet $3(2786.14 \mathrm{~g})$ and the values were similar to those on diets T2 (2743.41g) and T4 (2686.14g). However, diet 5 gave the lowest value (2312.73g) of weight compared to others. This may be attributed to effective utilization of nutrients in the diets. Soaking and fermentation proved to have reduced effectively the level of toxic compounds in the legume seeds [20]. The feed cost per kilogram. gain was significantly $(\mathrm{P}<0.05)$ better for birds fed Treatment 3 ( $(222.33)$ compared to others. There were significant differences $(\mathrm{P}<0.05)$ in the feed conversion ratio and better value was recorded at $15 \%$ soaked and fermented diets. This may be attributed to feed consumption and utilization of feed by birds [24]. This is also in line with work of [25] who reported that fermented parkia pulps can be effectively used to replace up to $20 \%$ of costly maize in the diets of Broiler Chickens with a concomitant reduction in feed costs associated with raising the birds

The results of carcass characteristics of broilers fed SFALBSM diets are presented in Table 7. Carcass weights and dressing percentages were significantly $(\mathrm{P}<0.05)$ affected the dietary inclusion of SFALBSM in the broiler chickens. Carcass weights were higher for birds fed 7.5 and $15 \%$ dietary diets (1942.05 and $1930.24 \mathrm{~g}$ respectively) compare to broiler chickens fed diet 5 containing $30 \%$ SFALBSM (1640.44g). Dressing percentages of birds were also higher in diets 1, 2 and 3 (73.92, 73.10 and $73.98 \%$ respectively) compared to others. The higher values of dressing percentages were attributed to feed consumption and utilization of feed by birds [26]. There were significant $(\mathrm{P}<0.05)$ effects of diets on the breast muscle, drum stick, and thigh muscles. The value on breast muscles was recorded highest in birds fed T3 $(21.97 \%)$ and lowest for those fed T5 (17.35\%). Drum stick was recorded highest in birds fed T2 $(12.50 \%)$ and lowest for birds fed T3 (10.74\%). This result agreed with the work of [27] and that of [28] who reported that processing improves the availability and good utilization of proteins and energy content of legumes seeds. Thigh muscle was significantly $(\mathrm{P}<0.05)$ highest for chickens fed T3 (13.38\%) compared to others. The wings, neck, and abdominal fat weights were not significantly $(\mathrm{P}>0.05)$ affected by dietary treatments of SFALBSM. The results for organs and guts measurements of broilers fed diets containing graded levels SFALBSM are presented in Tables8. There were significant differences $(\mathrm{P}<0.05)$ in the heart, lungs, liver, pancreas and kidney weights. This agrees with the findings of [28] and [29] who reported that liver is the organ involved in detoxification. Most of gut measurements were not significantly $(\mathrm{P}>0.05)$ influenced by the treatments, except the large intestine weight which had recorded higher value for birds fed T5 (0.94\%) and this was similar with values observed in control diet and $15 \%$ SFALBSM diet (0.91 and $0.92 \%)$. 


\section{Conclusion}

Based on this study, It is concluded that soaked and fermented African locust bean seed can be included in the diets of broiler finisher chickens up to $15 \%$ dietary level without any depression on growth with significant reduction in the feed cost of production

Table 1. Proximate compositions of Raw and Soaked and fermented African locust bean seed meal.

\begin{tabular}{lll}
\hline Parameter & Raw (\%) & SKFALSM (\%) \\
\hline Dry matter & 96.36 & 93.78 \\
Crude Protein & 24.31 & 28.56 \\
Crude fibre & 13.55 & 10.27 \\
Ether extract & 4.97 & 3.24 \\
Ash & 4.85 & 9.53 \\
Nitrogen Free Extract & 52.75 & 48.69 \\
\hline
\end{tabular}

*SFALBSM= Soaked and fermented African Locust bean Seed meal

Table 2. Levels of anti-nutritional factors and Percentage reduction by Soaking and fermentation of African Locust bean Seeds (SFALBS).

\begin{tabular}{llll}
\hline Anti-nutritional factors & Raw seeds & Soaked and FermentedSeeds & Percent Reductionof ANFs in SFALBS (\%) \\
\hline Tannin $(\mathrm{mg} / 100 \mathrm{~g})$ & 1.08 & 0.11 & 89.89 \\
Phytate $(\mathrm{mg} / 100 \mathrm{~g})$ & 0.71 & 0.17 & 76.05 \\
Saponin $(\mathrm{mg} / 100 \mathrm{~g})$ & 2.08 & 0.45 & 78.36 \\
Oxalate $(\mathrm{mg} / 100 \mathrm{~g})$ & 1.78 & 0.43 & 75.84 \\
Typsin inhiitor $(\mathrm{mg} / 100 \mathrm{~g})$ & 0.90 & 0.15 & 83.33 \\
\hline
\end{tabular}

Table 3. Composition of experimental diets for broiler starter containing graded levels of Soaked and fermented ALBSM.

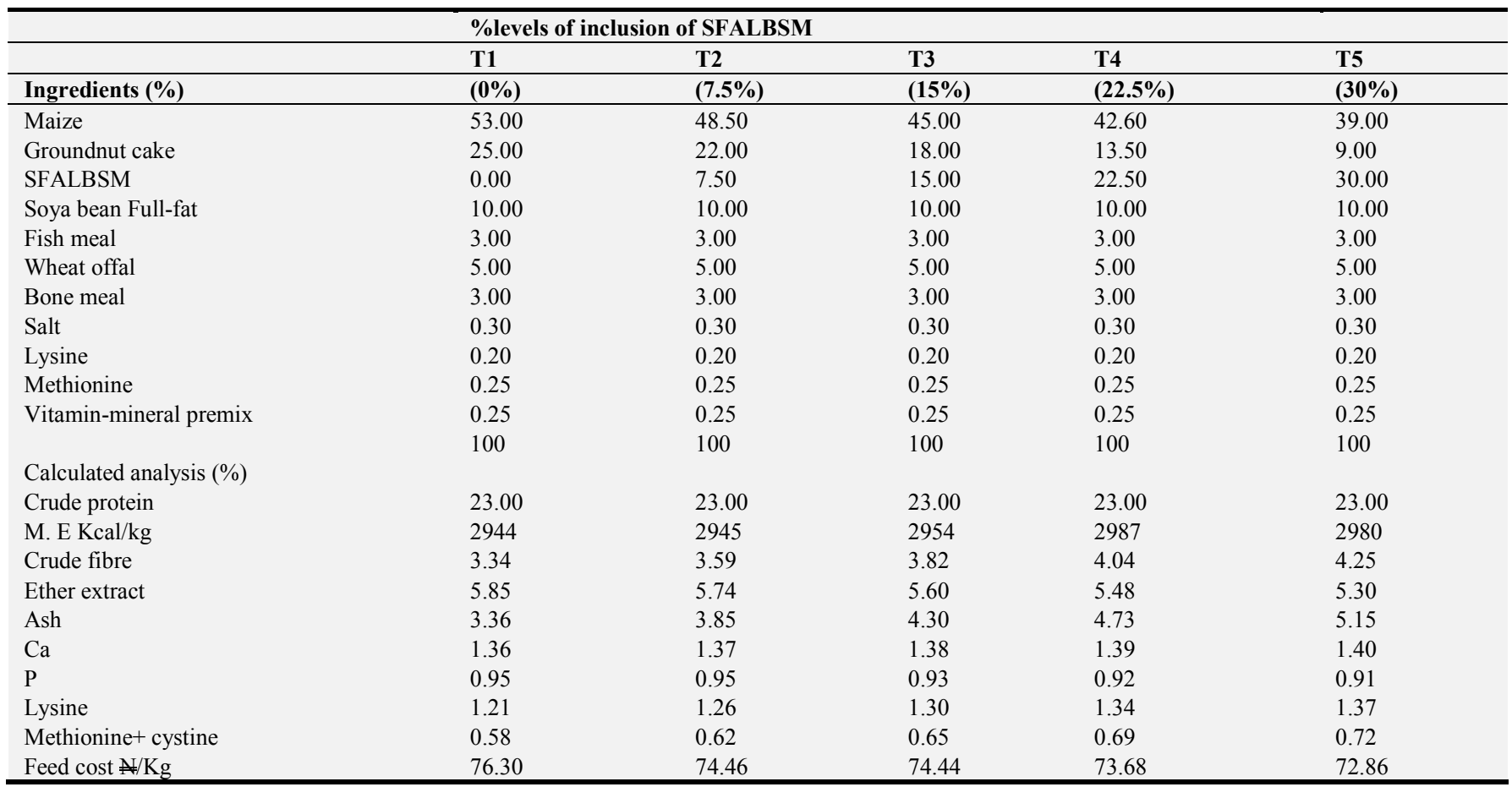

*Biomix premix supplied the following per kg of diet: Vit. A,10000 I.U., Vit. D, 2000 i.u; Vit k,2mg Vit.B1(Thiamine), 1.8mg; Vit B2 (Riboflavin), 5.5mg; Vit B6 (Pyridoxine), 0.3mg; Vit B12, 0.015mg; Pantothenic acid, 7.5mg; Folic acid, 0.75mg; Niacin, 27.5mg; Biotin, 0.6mg; Choline chloride, 3000mg; Cobalt, 0.2mg; copper, 3mg; Iodine, 1mg; Iron, 20mg; manganese, 40mg; Selenium, 0.2mg; Zinc, 30mg; Antioxidant, 1.25mg;

Table 4. Composition of experimental diets for broiler finisher containing graded levels of Soaked and fermented ALBSM.

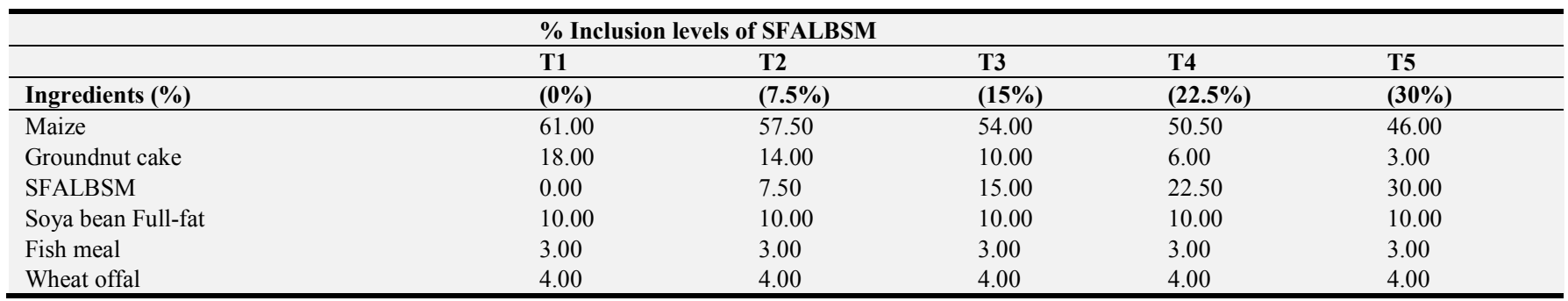




\begin{tabular}{llllll}
\hline & \% Inclusion levels of SFALBSM & & & \\
\hline & T1 & T2 & T3 & T4 & T5 \\
\hline Ingredients (\%) & $\mathbf{( 0 \% )}$ & $\mathbf{( 7 . 5 \% )}$ & $\mathbf{( 1 5 \% )}$ & $\mathbf{( 2 2 . 5 \% )}$ & $\mathbf{( 3 0 \% )}$ \\
\hline Bone meal & 3.00 & 3.00 & 3.00 & 3.00 & 3.00 \\
Salt & 0.30 & 0.30 & 0.30 & 0.30 & 0.30 \\
Lysine & 0.20 & 0.20 & 0.20 & 0.20 & 0.20 \\
Methionine & 0.25 & 0.25 & 0.25 & 0.25 & 0.25 \\
Vitamin-mineral premix & 0.25 & 0.25 & 0.25 & 0.25 & 0.25 \\
Calculated analysis (\%) & 100 & 100 & 100 & 100 & 100 \\
Crude protein & & & & \\
M. Energy Kcal/kg & 21.00 & 21.00 & 21.00 & 21.00 & 21.00 \\
Crude fibre & 3002 & 3011 & 3019 & 3019 & 3029 \\
Ether extract & 3.31 & 3.51 & 3.44 & 3.80 & 4.05 \\
Ash & 5.71 & 5.58 & 5.44 & 5.30 & 5.18 \\
Ca & 3.06 & 3.51 & 3.96 & 4.41 & 4.90 \\
P & 1.35 & 1.36 & 1.37 & 1.39 & 1.40 \\
Lysine & 0.93 & 0.92 & 0.91 & 0.90 & 0.90 \\
Methionine+ cystine & 1.11 & 1.15 & 1.19 & 1.23 & 1.29 \\
Feed cost N/Kg & 0.56 & 0.60 & 0.63 & 0.67 & 0.71 \\
\hline
\end{tabular}

*Biomix premix supplied the following per kg of diet: Vit A, 10000 I.U; Vit D3 2000 i.u.; Vit E, 23mg; Vit K,2mg; Vit K2mg; B1 (thiamine) 1.8mg; Vit B2 (Riboflavin), 5.5mg; Vit B6 (Pyridoxine),3.0mg; Vit. B12, 0.015mg; Pantothenic acid, 7.5mg; Folic acid, 0.75mg; Biotin, 0.06mg; Choline chloride, 300mg; Cobalt, $0.2 \mathrm{mg}$; copper, 3mg; Iodine, 1mg; Iron 20mg; manganese, 40mg; Selenium 0.2mg; Zinc, 30mg; Antioxidant, 1.25mg; M..E. = Metabolisable Energy and SFALBSM= Soaked and Fermented African Locust Bean Seed Meal.

Table 5. Performance of broiler chickens fed soaked and fermented African locust bean seed meal diets during starter phase (0-4weeks).

\begin{tabular}{|c|c|c|c|c|c|c|c|}
\hline \multirow[b]{2}{*}{ Parameters } & \multicolumn{7}{|c|}{ Level of Soaked and fermented African locust bean seed meal in Diets } \\
\hline & $0 \%$ & $7.5 \%$ & $15.00 \%$ & $22.5 \%$ & $30 \%$ & SEM & $\mathbf{P}$ \\
\hline Initial body weight (g) & 39.50 & 39.50 & 39.50 & 39.50 & 39.50 & 0.00 & 1.01 \\
\hline Final body weight (g) & $919.89^{\mathrm{a}}$ & $881.87^{\mathrm{b}}$ & $937.81^{\mathrm{a}}$ & $895.89^{\mathrm{b}}$ & $734.25^{\mathrm{c}}$ & 19.96 & 0.02 \\
\hline Total weight gain $(\mathrm{g})$ & $880.39^{\mathrm{a}}$ & $842.37^{\mathrm{a}}$ & $898.31^{\mathrm{a}}$ & $723.81^{\mathrm{b}}$ & $679.13^{\mathrm{b}}$ & 23.98 & 0.03 \\
\hline Total feed intake $(\mathrm{g})$ & $1708.56^{\mathrm{a}}$ & $1696.99^{\mathrm{a}}$ & $1672.72^{\mathrm{b}}$ & $1625.40^{\mathrm{c}}$ & $1572.39^{\mathrm{c}}$ & 6.24 & 0.01 \\
\hline Feed conversion ratio & $1.94^{\mathrm{b}}$ & $2.02^{\mathrm{b}}$ & $1.87^{\mathrm{c}}$ & $2.23^{\mathrm{a}}$ & $2.31^{\mathrm{a}}$ & 0.06 & 0.03 \\
\hline Feed cost $\# / k g$ gain & $148.19^{\mathrm{b}}$ & $152.20^{\mathrm{b}}$ & $137.51^{\mathrm{c}}$ & $163.44^{\mathrm{a}}$ & $168.71^{\mathrm{a}}$ & 4.72 & 0.02 \\
\hline Mortality rate (\%) & 2.22 & 4.00 & 4.33 & 4.44 & 0.00 & 3.08 & 0.82 \\
\hline
\end{tabular}

$\mathrm{abc}=$ mean with different superscripts on the same row are significantly different $(\mathrm{P}<0.05), \mathrm{SEM}=$ Standard error of means, $\mathrm{P}=$ probability.

Table 6. Performance of broiler chickens fed soaked and fermented Africanlocust beanSeed meal diets during finisher phase.

\begin{tabular}{|c|c|c|c|c|c|c|c|}
\hline \multirow[b]{2}{*}{ Parameters } & \multicolumn{7}{|c|}{ Level ofSoaked and fermented African locust bean seed meal in Diets } \\
\hline & $\mathbf{0 \%}$ & $7.5 \%$ & $15.00 \%$ & $22.5 \%$ & $30 \%$ & SEM & $\mathbf{P}$ \\
\hline Initial body weight $(\mathrm{g})$ & 1350.02 & 1350.03 & 1350.02 & 1350.03 & 1350.02 & 0.01 & 0.73 \\
\hline Final body weight $(\mathrm{g})$ & $2627.06^{\mathrm{b}}$ & $2743.41^{\mathrm{a}}$ & $2786.14^{\mathrm{a}}$ & $2686.14^{\mathrm{ab}}$ & $2312.73^{\mathrm{c}}$ & 35.06 & 0.01 \\
\hline Total weight gain $(\mathrm{g})$ & $1277.04^{\mathrm{b}}$ & $1424.73^{\mathrm{a}}$ & $1438.76^{\mathrm{a}}$ & $1336.16^{\mathrm{ab}}$ & $962.72^{c}$ & 32.85 & 0.02 \\
\hline Total feed intake $(\mathrm{g})$ & $4430.35^{\mathrm{a}}$ & $4430.91^{\mathrm{a}}$ & $4373.88^{a}$ & $4377.33^{a}$ & $4287.73^{b}$ & 26.46 & 0.02 \\
\hline Feed conversion ratio & $3.47^{\mathrm{b}}$ & $3.18^{\mathrm{ab}}$ & $3.05^{\mathrm{a}}$ & $3.26^{\mathrm{ab}}$ & $4.55^{\mathrm{c}}$ & 0.09 & 0.03 \\
\hline Feed cost $N / k g$ gain & $259.31^{\mathrm{b}}$ & $235.05^{\mathrm{c}}$ & $222.33^{\mathrm{c}}$ & $237.63^{\mathrm{bc}}$ & $316.70^{\mathrm{a}}$ & 6.99 & 0.04 \\
\hline
\end{tabular}

$a b c=$ mean with different superscripts on the same row are significantly different $(\mathrm{P}<0.05), \mathrm{SEM}=$ Standard error of means, $\mathrm{P}=\mathrm{Probability}$ value

Table 7. Carcass characteristics of broiler chickens fed soaked and fermented African locust bean seed meal diets at finisher phase.

\begin{tabular}{|c|c|c|c|c|c|c|c|}
\hline & $\%$ Inclus & Is ofsoaked & fermented Afr & n locust bean & 1 meal & & \\
\hline Parameters & T1 (0\%) & T2 (7.5\%) & T3 (15.00\%) & T4 (22.5\%) & T5 (30\%) & SEM & $\mathbf{P}$ \\
\hline Final live weight ( $\mathrm{g} / \mathrm{bird})$ & $2621.04^{b}$ & $2740.09^{\mathrm{a}}$ & $2780.20^{\mathrm{a}}$ & $2680.13^{\mathrm{ab}}$ & $2290.11^{\mathrm{c}}$ & 30.09 & 0.01 \\
\hline Carcass weight ( $\mathrm{g} / \mathrm{bird})^{*}$ & $1820.02^{b}$ & $1942.05^{\mathrm{a}}$ & $1930.24^{\mathrm{a}}$ & $1750.33^{\mathrm{bc}}$ & $1640.44^{\mathrm{c}}$ & 54.00 & 0.03 \\
\hline Dressing percentage & $73.92^{\mathrm{a}}$ & $73.10^{\mathrm{a}}$ & $73.98^{\mathrm{a}}$ & $70.20^{\mathrm{b}}$ & $70.04^{\mathrm{c}}$ & 0.36 & 0.04 \\
\hline Breast muscle & $19.55^{\mathrm{b}}$ & $19.68^{b}$ & $21.97^{\mathrm{a}}$ & $19.87^{b}$ & $17.35^{\mathrm{c}}$ & 0.55 & 0.03 \\
\hline Drum stick & $11.52^{\mathrm{a}}$ & $12.50^{\mathrm{a}}$ & $10.74^{\mathrm{a}}$ & $12.29^{\mathrm{b}}$ & $11.60^{\mathrm{a}}$ & 0.63 & 0.02 \\
\hline Thigh & $11.63^{\mathrm{b}}$ & $11.78^{\mathrm{b}}$ & $13.38^{\mathrm{a}}$ & $12.57^{\mathrm{ab}}$ & $11.76^{\mathrm{b}}$ & 0.31 & 0.01 \\
\hline Wings & 9.41 & 9.25 & 9.94 & 9.47 & 9.39 & 0.46 & 0.67 \\
\hline Neck weight & 6.55 & 7.89 & 8.17 & 7.14 & 7.9 & 0.11 & 0.34 \\
\hline Back weight & $21.32^{\mathrm{a}}$ & $19.69^{c}$ & $22.23^{\mathrm{a}}$ & $19.53^{\mathrm{c}}$ & $20.21^{\mathrm{b}}$ & 0.76 & 0.03 \\
\hline Abdominal fat & 2.52 & 2.74 & 2.62 & 2.71 & 2.53 & 0.12 & 0.43 \\
\hline
\end{tabular}

$\mathrm{abc}=$ mean with different superscripts on the same row are significantly different $(\mathrm{P}<0.05), \mathrm{SEM}=$ Standard error of means, $\mathrm{P}=$ Probability value 
Table 8. Organs and guts weight of broiler chickens fed soaked and fermented African locust bean seed meal diets at finisher phase.

\begin{tabular}{|c|c|c|c|c|c|c|c|}
\hline \multirow[b]{2}{*}{ Parameters } & \multicolumn{7}{|c|}{ \% Inclusion levels ofsoaked and fermented African locust bean seed meal } \\
\hline & T1 (0\%) & T2 $(7.5 \%)$ & T3 (15\%) & T4 (22.5\%) & T5 $(30 \%)$ & SEM & $\mathbf{P}$ \\
\hline Heart & $0.45^{\mathrm{c}}$ & $0.50^{\mathrm{a}}$ & $0.50^{\mathrm{a}}$ & $0.51^{\mathrm{a}}$ & $0.49^{\mathrm{b}}$ & 0.01 & 0.02 \\
\hline Lungs & $0.59^{\mathrm{ab}}$ & $0.58^{\mathrm{ab}}$ & $0.70^{\mathrm{a}}$ & $0.50^{\mathrm{b}}$ & $0.62^{\mathrm{ab}}$ & 0.03 & 0.04 \\
\hline Pancreas & $0.32^{\mathrm{a}}$ & $0.20^{\mathrm{b}}$ & $0.20^{\mathrm{b}}$ & $0.30^{\mathrm{a}}$ & $0.28^{\mathrm{a}}$ & 0.02 & 0.01 \\
\hline Kidney & $0.28^{\mathrm{b}}$ & $0.33^{\mathrm{ab}}$ & $029^{\mathrm{b}}$ & $0.38^{\mathrm{a}}$ & $0.34^{\mathrm{a}}$ & 0.02 & 0.02 \\
\hline Crop & 0.09 & 0.11 & 0.10 & 0.09 & 0.09 & 0.02 & 0.38 \\
\hline Gizzard (\%) & 2.76 & 2.73 & 2.70 & 2.72 & 2.65 & 0.04 & 0.30 \\
\hline Small intestine weight & 2.20 & 2.17 & 2.22 & 2.22 & 1.97 & 0.17 & 0.78 \\
\hline Small intestine length $(\mathrm{cm})$ & 246.01 & 277.12 & 272.23 & 260.41 & 261.78 & 9.58 & 0.44 \\
\hline Large intestine weight & $0.91^{\mathrm{ab}}$ & $0.83^{\mathrm{b}}$ & $0.92^{\mathrm{ab}}$ & $0.85^{\mathrm{b}}$ & $0.94^{\mathrm{a}}$ & 0.05 & 0.03 \\
\hline Large intestine length $(\mathrm{cm})$ & 37.02 & 35.06 & 34.53 & 35.54 & 34.95 & 0.78 & 0.78 \\
\hline
\end{tabular}

$\mathrm{abc}=$ mean with different superscripts on the same row are significantly different $(\mathrm{P}<0.05), \mathrm{SEM}=\mathrm{Standard}$ error of mean, $\mathrm{P}=\mathrm{Probability}$ value.

\section{References}

[1] Ogundipe, S. O. Non-conventional poultry feedstuffs from research to practice; A paper presented at the poultry Farmers Workshop, N. A. E. R. L. S. at Ahmadu Bello University Zaria, Nigeria, 1987, pp 1-10.

[2] Kehinde. A. S., Babatude, T. O., Ayoola, O. A. and Temowo, O. O. Effect of different level of protein on the growth performance characteristics of broiler chicks. In: proceeding $31^{\text {st }}$ Annual Conference of the Nigerian Society for Animal Production, $12^{\text {th }}-15^{\text {th }}$ March, Bayero University Kano, Nigeria, 2006, pp 325-237.

[3] Longe, O. G. Poultry: Treasure in chest, an inaugural lecture delivered at University of Ibadan Nigeria, 2006, 1-10.

[4] Bamgbose, A. M., Isah, O. A., Sobayo, R. A., Oso, A. O., Okeke, E. N. and Alonge, A. S. Utilization of bovine Blood rumen digesta mixture based diets by cockerels chicks. In: Proceeding of $36^{\text {th }}$ Annual conference of the Nigerian Society for Animal Production, $13^{\text {th }}$-16t march, Abuja, 2011, 391-394.

[5] Oyawoye, E. O. Rabbit production as a means of supplying cheap animal protein in Nigeria. Nigerian Livestock Farmers 9, 1989, 11-14.

[6] Omoikhoje, S. O., Bamgbose, A. M. and Aruna, M. B. Replacement value of unpeeled cassava root meal (UPCRM) for maize in weaner rabbit diets. Nigerian Journal of Animal production 35 , 2008, 63-68.

[7] Bamgbose, A. M., Ogunbero, S. D., Obasohan, E. E., Aruna, A. M., Oleku, L. T. and Igene, U. F.. Replacement value of maize offal /Cashew nut for maize in the diet of broilers In: proceeding of $29^{\text {th }}$ annual conference of the Nigerian Society for Animal Production, 2004, 219-221.

[8] Uzegbu, H. O., Ndekekwute, E. K. and Abdu, L. Effect of inclusion of Bambara ground nut (Voandezea subteranemea) waste meal on metabolizable energy and protein of broiler chickens. In: Proceeding of the $41^{\text {st }}$ Annual Conference of Agricultural Society of Nigeria, 2007, 348-352.

[9] Dafwang, I., Ikani, E. J., Chikwendu, D. O., Adesehinwa, A. O. K., Annate, A. I. and Iwuayanwu, I. E. J. An assessment of adoption of non-conventional feedstuffs. Poultry and Rabbit Research, (3), 2001. 3-5.

[10] Adebowale, K. O. and Lawal, O. S. Comparative study of the functional properties of Bambara groundnut (Voudzea subterranean), Jack bean (Canavalia ensiformis) and Mucuna bean (Mucuna pruperien). Food Research International, 37, 2004,: 355-365.

[11] Vijayakumari, K., Siddhuraju, P. and Janardhanan, Effect of domestic processing on level of certain anti-nutrients in Prosopis chilensis (Molina) stuntz seeds. Food Chemistry Journal 59 (3), 1997, 367-371.

[12] Dike, E. N. and Odunfa, S. A. Microbiology and biochemical evaluation of fermented soya bean products. (Soya dawadawa). Journal of Food Science Technology, 40, 2003, 606-610.

[13] Oyenuga, V. A. Nigeria's food and feeding stuffs, Ibadan, $1^{\text {st }}$ edition, University press. Ibadan. Nigeria, 1968, 50-54.

[14] Campbell-platt, G. African locust bean and its West African fermented seeds in Nigeria. Journal of Agricultural Food Chemistry, 34 1980). 189-192.

[15] Olomu, J. M.. Monogastric Animal Nutrition; Principles and Practice. $2^{\text {nd }}$ Edition University of Benin, Jackson publishers. Nigeria, 2011, 160-165.

[16] Olofin, E. A., Nabegu, A. B. and Dambazau, A. M. Wudil within Kano region; A geographical synthesis, $1^{\text {st }}$ edition, Adamu joji publishers. Kano State, Nigeria, 2008, pp. 134-138.

[17] A. O. A. C. Official Methods of Analysis, Association of official Analytical Chemist, Washington DC., 1990, Pp 423858.

[18] SAS Statistical Analysis System User Guide for Statistics Version 10. SAS institute Inc, Carolina, 2002, U. S. A

[19] Walter, E., Collin, E., Philips, R. and Goodrich, M. V. Understanding Agricultural waste recycling, Technical Review, 1984, 84.

[20] Ologhobo, A. D., Apata, D. F., Oyeyide, A. and Akinpelu, R. O. A comparison of protein fractions prepared from Limaneans (phaseolus luntus) in starter diets for broiler chicks. Journal. Applied. Animal Research. 4:,1993,13-30.

[21] Odebunmi, E. O., Oluwaniyi, O. O., Bashiru, M. O., Comparative proximate Analysis of some Food Condiments. Journal of Applied Sci. Res., 6, 2010, 272-274.

[22] Simovic, R.; Summers, J. D. and Bilanski, W. K. Heat treatment of full fat soybean Canadian Journal of Animal Science 52: 1972, 183-188. 
[23] Williams, B. A., Verstagen, M. W. A., and Tamminga, S. Fermentation in the Large Intestine of Single-stomached Animals and its Relationship to Animal Health. Nutri. Res., Rev.,14: 2001,207-228

[24] Amaefule, K. U. and Obioha, F. C. Performance and nutrient utilization of broiler starters fed diets containing raw boiled or dehulled pigeon pea seeds (Cajanus cajan) Nigerian Journal of Animal Production, 28 (1), 2001,31-39.

[25] Lakurbe, O. A., Madu,, H. K., Begel, B. J. and Mohammed, F. Effect of Feeding Fermented African Locust Bean (Parkia Biglobosa) Fruit Pulps Based Diets On Growth Performance and Carcass Characteristics Of Broiler Chickens, Researchjournali's Journal of Agriculture, 2 (12), 2015

[26] Omeje, S. I. Issues in Animal Science, Raykennedy Scientific Publication Enugu, Nigeria, 1999, pp 31-34.
[27] Kaankuka, F. G. Balogun, T. F., Bawa, G. S. and Duru, S. Effect of cooking soybean on dry matter digestibility and Energy in pigs. Indian Journal of Animal Science, 70 (7), 2000, 740-743.

[28] Ukachukwu, S. N., Ezeagu, I. E., Tarawali, G. and Ikeorgu, J. E. G. Utilization of Mucuna as a food and feed in West Africa. In: Proceedingof International Workshop on feeds. Tegucigalpa, Honduras, 2000, 189-227.

[29] Akinmutimi, A. H. Evaluation of sword bean (Canavalia gladiate) as an alternative resource for broiler chicken. A Ph. D Thesis College of Animal Science and Health, Micheal Okpara University of Agriculture, Umudike, Abia State, 2004, 74-100. 